\title{
Combining ability $\times$ environment interaction and genetic analysis for agronomic traits in safflower (Carthamus tinctorius L.): $_{\text {. biplot as a tool for }}$ diallel data
}

\author{
Pooran GOLKAR ${ }^{1 *}$, Ehsan SHAHBAZI ${ }^{2}$, Mojtaba NOURAEIN $^{3}$
}

Received June 19, 2016; accepted February 27, 2017.

Delo je prispelo 19. junija 2016, sprejeto 27. februarja 2017.

\begin{abstract}
Combining ability $\times$ environment interaction is considerable to identify the effect of environment on the combining ability and gene action of the traits to select appropriate parents for safflower hybrid production. The 36 genotype $\left(28 \mathrm{~F}_{2}\right.$ progenies of eight-parent half-diallel crosses across 8 parental genotypes) of safflower were studied to investigate the mentioned parameters across different geographical regions of Iran. The results indicated significant differences among parents for general and specific combining ability, except for seeds per capitulum across three environments. The overall results indicated that $K_{21}$ and Mex.22-191 were excellent parents with greater general combining ability for the improvement of seed yield in safflower. The $\mathrm{K}_{21} \times$ Mex.22191 hybrid could be, therefore, employed for the production of high seed yield in safflower breeding. The estimates of genetic variance components recommended the importance of additive- dominance genetic effects that contributed to variation in yield per plant. Such gene action expression for seed yield needs auxiliary methods based on hybridization and selection for seed yield advancement in safflower.
\end{abstract}

Key words: combining ability; heritability; oil seed; and variance component
IZVLEČEK

\author{
ANALIZA INTERAKCIJE OKOLJA IN \\ KOMBINACIJSKE SPOSOBNOSTI IN GENETSKA \\ ANALIZA AGRONOMSKIH LASTNOSTI ŽAFRANIKE \\ (Carthamus tinctorius L.): BIPLOT KOT ORODJE ZA \\ ANLIZO DIALELNIH KRIŽANJ
}

Preučevanje kombinacijske sposobnosti križancev in interakcije okolja je pomembno pri določanju učinkov okolja na uspešnost križancev in delovanja genov na določene lastnosti pri izbiri primernih starševkih rastlin žafranike pri pridobivanju hibridov. Preučevanih je bilo 36 genotipov žafranike $\left(28 \mathrm{~F}_{2}\right.$ potomcev osmih starševskih pol dialelnih križanj z 8 starševskimi genotipi), da bi preučili odziv analiziranih parametrov $\mathrm{v}$ različnih geografskih območjih Irana. Izsledki so pokazali značilne razlike med starševskimi rastlinami za splošne in specifične kombinacijske sposobnosti razen za število rožk na košek v treh preučevanih okoljih. Celokupni rezultati so pokazali, da sta bila $\mathrm{K}_{21}$ in Mex.22-191 odlična starša $\mathrm{z}$ večjo splošno kombinacijsko sposobnostjo za izboljšanje pridelka semena žafranike. Hibrid $\mathrm{K}_{21} \times$ Mex.22191 bi lahko bil uporabljen pri žlahtnjenu žafranike za doseganje velikih pridelkov semena. Ocenjene komponente genetske variance kažejo na pomembnost aditivnodominantnih genetskih učinkov, ki vplivajo na spreminjanje pridelka na rastlino. Preučevanje takšnega izražanja genov, ki vpliva na pridelek semena žafranike potrebuje dodatne metode, ki temeljijo na hibridizaciji in selekciji za povečanje pridelka.

Ključne besede: kombinacijska sposobnost; heritabilnost; oljna semena; komponente variance

\footnotetext{
1 Research Institute for Biotechnology and Bioengineering, Isfahan University of Technology, Isfahan 8415683111, Iran; corresponding author: golkar@cc.iut.ac.ir

2 Department of Agronomy and Plant breeding, Faculty of Agriculture, Shahrekord University, Shahrekord, 8818634141, Iran

3 Department of Agronomy and Plant breeding, Faculty of Agriculture, Maragheh University, 5518183111, Iran
} 


\section{INTRODUCTION}

Safflower (Carthamus tinctorius L.) $(\mathrm{n}=12)$ is one of human's oldest crops that has been traditionally grown for the production of vegetable oils, fabric dyes, food coloring, industrial and medicinal properties (Dajue and Mundel 1996; Weiss 2000). After oil extraction, the resultant meal is used for animal feed as it is rich in proteins (Singh 2007). It may have some production potential under arid and semi - arid regions (Kizil et al 2008). Cultivars with increased content of seed yield are required for safflower production in comparison with other oilseeds (Mohammadi and Pourdad, 2009; Golkar 2014). Iran and Mediterranean region are considered as rich centers for safflower (Knowles 1969) with diverse agro-ecological regions contributing to the increase in area and production of safflower (Golkar 2014). Annual yield of safflower production is about 700 tha $^{-1}$ in Iran. Crop yield improvement requires adequate knowledge regarding the nature of parents combining ability that are available for hybridization programs and the nature of gene action included in the expression of quantitative traits of economic importance (Nassimi et al 2006; Milic et al 2011; Acquaah 2012; Gouda et al 2013). The variance for General Combining Ability (GCA) includes the additive portion of the total variance, whereas that for Specific Combining Ability (SCA) involves the nonadditive portion of the total variance, which arises from dominance and epistatic deviations (Sincik et al 2011; Acquaah 2012). Specific combining ability is an important indicator of the potential of inbred lines for generating superior hybrid combinations (Singh and Pawar 2005; Zhang et al 2015).

Diallel analysis is the most common genetic design that is used for determining combining abilities (Singh and
Pawar 2005; Bocanski et al. 2011). Some methods are available to analyze diallel crosses, such as the method developed by Griffing (1956). Biplot method for analysis of diallel data reports the inter-relationships and combining ability of parents based on graphical presentation, using $\mathrm{PC}_{1}$ and $\mathrm{PC}_{2}$, which are derived through principle component (PC) analysis of environment-centered yield data (Yan and Hunt 2002). In this relation, the knowledge of genetic control and combining abilities can be useful for improvement of seed yield, allocation of new genetic resources and construction of selection indices in safflower (Milic et al 2011; Suresh et al 2013). Reports on the combining ability and the inheritance of some agronomic traits in safflower are available (Mandal and Banerjee 1997; Gupta and Singh 1988; Singh et al 2005; Golkar et al., 2012), but literature review has shown that there is no information regarding the effects of different environments on the magnitude of general and specific combining ability and their interaction with environments for important agronomic traits in safflower, especially in the Middle east region. The genotype $\times$ environment interaction is a major source of bias that affects general and specific combining ability testing (Suresh et al 2013). Improvement of new hybrids adapted to world climate modification is an important breeding stage to sustain safflower production in Iran. The objectives of the present research were 1) to determine genetic parameters and the mode of inheritance for seed yield and its components in safflower, and 2) to identify best combinations for seed yield and its components in safflower hybrids across different geographical environments.

\section{MATERIALS AND METHODS}

\subsection{Plant material and experimental design}

The seeds of 36 genotypes ( 8 parents and $28 \mathrm{~F}_{2}$ hybrids) were originated by a $8 \times 8$ half-diallel design in $\mathrm{F}_{2}$ generation. The cultivars were hand-crossed with emasculation in a diallel mating design. Eight safflower genotypes including six local Iranian genotypes: $\mathrm{C}_{111}$ (selected from Kouseh landrace), $\mathrm{C}_{4110}$ (selected from Kouseh landrace), $\mathrm{ISF}_{14}$ (selected from Isfahan), $\mathrm{A}_{2}$ (selected from Azarbayejan), $\mathrm{K}_{21}$ (selected from Kordestan) and IL.111 (selected from Auromyeh), with two exotic genotypes from Mexico (Mex.22-191) and Germany $\left(\mathrm{GE}_{62918}\right)$. Iranian genotypes were selected on the basis of their differences in geographical origin, adaptability and morphologic characters. In the $F_{2}$ generation, evaluation was made in three geographical environments. The seeds of 36 genotypes ( 8 parents, 28
$F_{2}$ hybrids) were sown at three different research farms that were located in different regions of Iran including (Isfahan: $51^{\circ} 32^{\prime} \mathrm{E}$ and $32^{\circ} 32^{\prime} \mathrm{N}, 1630 \mathrm{~m}$ asl, dry and hot climate), Maragheh $\left(46^{\circ} 12^{\prime} \mathrm{E}\right.$ and $37^{\circ} 30^{\prime} \mathrm{N}$, $1477.7 \mathrm{~m}$ asl, cold and wet climate ) and Shahrekord $\left(49^{\circ} 22^{\prime} \mathrm{E}\right.$ and $32^{\circ} 20^{\prime} \mathrm{N}, 2060 \mathrm{~m}$ asl, cold and dry climate) in spring of 2015 by using a randomized complete block design with three replications. The mean of annual temperature at Isfahan, Shahrekord and Maragheh were recorded $19.5^{\circ} \mathrm{C}, 11.5^{\circ} \mathrm{C}$ and $13.5^{\circ} \mathrm{C}$, respectively. The soil at three location farms were silty clay loam, typical Haplargids of the arid tropic with $\mathrm{pH}$ 7 (Maragheh) to 7.5 (Isfahan and Shahrekord). Plots of parents consisted of 1 rows of $2.5 \mathrm{~m}$ length, whereas $F_{2}$ progenies consisted of 3 rows of $2.5 \mathrm{~m}$ length. The plants were spaced $50 \mathrm{~cm}$ and $5 \mathrm{~cm}$ between and within rows. To raise the crop, plot was fertilized with $200 \mathrm{~kg}$ 
$\mathrm{ha}^{-1} \mathrm{~N}$ and $200 \mathrm{~kg} \mathrm{ha}^{-1} \mathrm{P}_{2} \mathrm{O}_{5}$ previous of sowing and $100 \mathrm{~kg} \mathrm{ha}^{-1} \mathrm{~N}$ was applied bout one month after planting. The standard agronomic practices for safflower were followed during the growing season. From each plot, 30 competitive progenies were selected randomly for recording observations on studied traits including: capitula per plant (CP), seeds (achenes) per capitulum (SC), 1000-seed mass (g) (SW) and yield per plant (g) (YP).

\subsection{Statistical analysis}

The data were first subjected to the Analysis of variance (ANOVA) by using General Linear Model of SAS program (SAS, 2011).The mean of each plot was used for statistical analysis.

The least significant Difference (LSD $5 \%$ ) test was used for mean separation. Combining abilities (general and specific) were estimated following Method 2 Model1 described by Griffing (1956) via SAS program (Zhang et al., 2005) based on the following statistical model:

$$
X \mathrm{ijk}=m+g_{i}+g_{j}+s_{i j}+e_{i j k}(1)
$$

in each location, where, $X_{i j k}$ is the observed value for a cross between the $i_{\text {th }}$ and $j_{\text {th }}$ parents in the $\mathrm{k}_{\text {th }}$ replication, $m$ is population mean; $g_{i}$ and $g_{j}$ are GCA values of the $i_{\text {th }}$ and $j_{\text {th }}$ parents, respectively; $s_{i j}$ is the SCA value for the hybrid between the $i_{\text {th }}$ and $j_{\text {th }}$ parents and $e_{i j k}$ is the residual. Combined analysis over locations for combining ability analysis, genetic parameters $\left(\delta_{\mathrm{A}}^{2}\right.$ and $\delta_{\mathrm{D}}^{2}$ ) and heritability estimates (broad sense and narrow sense heritability) was conducted according to Perkins (1970) by the following formulae:

$$
\begin{aligned}
& h_{b}^{2}=\sigma_{G}^{2} /\left(\sigma_{G}^{2}+\frac{\sigma_{G E}^{2}}{s}+\sigma_{e}^{2}\right)(2) \text { and } \\
& h_{n}^{2}=\sigma_{A}^{2} /\left(\sigma_{G}^{2}+\frac{\sigma_{G E}^{2}}{s}+\sigma_{e}^{2}\right)(3)
\end{aligned}
$$

The genetic components were estimated according to Perkins (1970):

$$
\begin{aligned}
& \sigma_{G}^{2}=2 \sigma_{G C A}^{2}+\sigma_{S C A}^{2} \\
& \sigma_{G \times E}^{2}=2 \sigma_{G C A \times E n v}^{2}+\sigma_{S C A \times E n v}^{2}
\end{aligned}
$$

The dominance ratio (Singh \& Pawar, 2005) which explains the ratio of dominance to additive gene effects was calculated using following equation:

$$
\sqrt{\frac{2 \sigma^{2} D}{\sigma_{A}^{2}}}
$$

\subsection{Biplot interpretations}

GGE biplot analysis is expressed as: $Y_{\mathrm{ij}}-\beta \mathrm{j}=\lambda_{1} \varepsilon_{\mathrm{i} 1} \eta_{\mathrm{j} 1}+$ $\lambda_{2} \varepsilon_{\mathrm{i} 2} \eta_{\mathrm{j} 2}+$ eij Where, $\mathrm{Y}_{\mathrm{ij}}$ is genotypic values of the combination ( $\mathrm{F}_{2}$ hybrids) between genotypes $\mathrm{i}$ and tester $\mathrm{j}$ for a given trait; $\beta \mathrm{j}$ average value of all combinations with tester $\mathrm{j}, \lambda_{1}$ and $\lambda_{2}$ are singular values for $\mathrm{PC} 1$ and $\mathrm{PC} 2$. The $\varepsilon_{\mathrm{i} 1}$ and $\varepsilon_{\mathrm{i} 2}$ are $\mathrm{PC}_{1}$ and $\mathrm{PC}_{2}$ eigenvectors for genotypes i (entry), respectively; $\eta_{\mathrm{j} 1}$ and $\eta_{\mathrm{j} 2}$ are $\mathrm{PC}_{1}$ and $\mathrm{PC}_{2}$ eigenvectors for tester $\mathrm{j}$, respectively; eij is the residual of model for inbred $i$ and tester $j$ (Yan \& Hunt 2002). In diallel crosses, a parent is both an entry and a tester (Yan \& Hunt 2002). Biplot analysis for seed yield per plant done by GGE biplot software (Yan 2001).

\section{RESULTS AND DISCUSSION}

\subsection{Combining ability analysis in individual locations}

The analysis of variance for the combining ability of evaluated traits for each individual location (Isfahan, Maragheh and Shahrekord) is presented in Table 1. Analysis of variance revealed significant genotypic differences for all studied traits in Isfahan (Table 1a). Combining ability analysis also showed that GCA and SCA mean squares were significant for all traits studied. The combining ability analysis in Maragheh revealed that the genotypes showed a significant difference for all studied traits (Table 1b). The mean squares of GCA were significant for all studied traits (Table 1b). The SCA mean squares were not significant for seed mass (Table 1b). The analysis of variance in Shahrekord revealed a significant difference between genotypes for all studied traits (Table 1C). The mean squares of GCA were significant for capitula per plant, seeds per capitulum and yield per plant (Table $1 \mathrm{C}$ ). The SCA mean squares were also significant for capitula per plant, seeds per capitulum and yield per plant (Table 1C). The total comparison of GCA and SCA mean squares presented different ratios of $\delta_{\text {gcal }}^{2} \delta_{\text {sca }}^{2}$ (Table 1). Genetic differences were more pronounced under high temperatures (Isfahan) than the low ones (Shahrekord and Maragheh). Also, such other factors as location altitude and relative rainfall might have played a role in the expression of genotypic differences in each location. According to the obtained results, under cold and dry climates (Shahrekord), genotype differences were less pronounced for traits; so, intercrossing of candidate genotypes at this location would result in flat breeding (Barten et al 1993). 
Pooran GOLKAR et al.

Table 1: Analysis of variance for combining ability for agronomic traits in safflower under different environment

\begin{tabular}{|c|c|c|c|c|c|}
\hline \multirow[b]{2}{*}{ Isfahan } & \multirow[b]{2}{*}{ df } & \multicolumn{4}{|c|}{ Mean squares of studied traits } \\
\hline & & $\mathrm{CP}$ & SC & SW & YP \\
\hline Replication & 2 & $9.39^{* *}$ & $27.47^{* *}$ & 1.5 & $45.52^{* *}$ \\
\hline Genotype & 35 & $11.66^{* *}$ & $194.73^{* *}$ & $49.52^{* *}$ & $172.33^{* *}$ \\
\hline GCA & 7 & $37.99^{* *}$ & $833.52^{* *}$ & $194.32^{* *}$ & $594.14^{* *}$ \\
\hline SCA & 28 & $5.08^{*}$ & $35.04^{* *}$ & $13.32^{* *}$ & $66.88^{* *}$ \\
\hline Error & 70 & 2.95 & 2.09 & 5.9 & 2.94 \\
\hline$\delta_{\mathrm{GCA}}^{2}$ & & 1.10 & 26.62 & 6.03 & 17.58 \\
\hline$\delta_{\text {SCA }}^{2}$ & & 0.71 & 10.98 & 2.47 & 21.31 \\
\hline$\delta_{\mathrm{A}}^{2}$ & & 2.19 & 53.23 & 12.07 & 35.15 \\
\hline$\delta_{D}^{2}$ & & 0.71 & 10.98 & 2.47 & 21.31 \\
\hline Maragheh & df & $\mathrm{CP}$ & $\mathrm{SC}$ & SW & YP \\
\hline Replication & 2 & 6.52 & 42.14 & 66.61 & $148.34^{* *}$ \\
\hline Genotype & 35 & $7.52^{* *}$ & $39.4^{* *}$ & $60.07^{* *}$ & $77.38^{* *}$ \\
\hline GCA & 7 & $19.14^{* *}$ & 35.07 & $153.12^{* *}$ & $237.39^{* *}$ \\
\hline SCA & 28 & $4.59^{*}$ & $40.47^{* *}$ & 36.78 & $37.35^{*}$ \\
\hline Error & 70 & 2.86 & 18.52 & 23.58 & 22.6 \\
\hline$\delta_{\mathrm{GCA}}^{2}$ & & 0.49 & 0 & 3.88 & 6.67 \\
\hline$\delta_{\mathrm{SCA}}^{2}$ & & 0.58 & 7.32 & 4.40 & 4.92 \\
\hline$\delta_{\mathrm{A}}^{2}$ & & 0.97 & 0.00 & 7.76 & 13.34 \\
\hline$\delta_{\mathrm{D}}^{2}$ & & 0.58 & 7.32 & 4.40 & 4.92 \\
\hline Shahrekord & $\mathrm{df}$ & $\mathrm{CP}$ & $\mathrm{SC}$ & SW & YP \\
\hline Replication & 2 & $23.06^{* *}$ & $49.03^{*}$ & $99.59^{* *}$ & 3.88 \\
\hline Genotype & 35 & $14.41^{* *}$ & $130.03^{* *}$ & $60.92^{* *}$ & $159.37^{* *}$ \\
\hline GCA & 7 & $25.83^{* *}$ & $532.35^{* *}$ & $243.21^{* *}$ & $514.26^{* *}$ \\
\hline SCA & 28 & $11.55^{* *}$ & $29.43^{* *}$ & 15.33 & $70.35^{* *}$ \\
\hline Error & 70 & 2.83 & 14.09 & 14.85 & 4.16 \\
\hline$\delta_{\mathrm{GCA}}^{2}$ & & 0.48 & 16.76 & 7.60 & 14.80 \\
\hline$\delta_{\mathrm{SCA}}^{2}$ & & 2.91 & 5.11 & 0.16 & 22.06 \\
\hline$\delta_{A}^{2}$ & & 0.95 & 33.53 & 15.19 & 29.59 \\
\hline$\delta_{\mathrm{D}}^{\mathrm{A}}$ & & 2.91 & 5.11 & 0.16 & 22.06 \\
\hline
\end{tabular}

* and ** significant at $P<0.05$ and $P<0.01$, respectively;

CP: capitula per plant, SC: seeds per capitulum, SW: 1000-seed weight, YP: yield per plant.

\subsection{Combining ability across all locations}

Information on the relative importance of general and specific combining ability can be helpful in the analysis and interpretation of the genetic basis of important traits in safflower. Analysis of variance combined over environments showed that different environments had a significant effect on all studied traits (Table 2). The results obtained from the combined analysis of variance indicated a significant genotypic difference in $\mathrm{F}_{2}$ diallel experiment for all traits studies (Table 2). Combined analysis of variance for combining ability over three locations revealed that GCA mean squares were highly significant for all the traits (Table 2). The SCA mean square was highly significant, except for SCA of seeds per capitulum (Table 2). This result implied that selection for the improvement of seeds per capitulum could be delayed to later generations until the nonadditive portion would be mitigated to the additive portion as this trait showed the higher magnitude of SCA variance, as compared to GCA variance in the respective location. The proportion of $\delta^{2}$ gca to $\delta^{2}$ sca varied from trait to trait. On the other hand, the proportion of $\delta_{\text {gca }}^{2}: \delta^{2}$ SCA showed that most total genetic variability for seeds per capitulum and seed mass was more associated with GCA (fixable genetic portion) than SCA (non- fixable genetic portion) effects (Table 
2); thus simple selection would confer the rapid improvement of these traits.

The genotype $\times$ environment interaction was significant for seeds per capitulum and yield per plant (Table 2), thereby suggesting significant variation among $F_{2}$ genotypes for the mentioned traits in their sensitivity to the geographical location. The conditions in this experiment were favorable for detecting genotype $x$ environment interactions, since different temperatures in three locations represented extreme environmental conditions under which high seed yield safflower genotypes could be commercially grown (Suresh et al 2013). Thus, for population improvement of $F_{2}$ hybrid combinations, evaluation of capitula per plant and seed mass should be sufficient in one location.

With considering to combining abilities (GCA and SCA) interaction with different locations, GCA $\times$ location interaction was significant for all studied traits, except for seed mass (Table 2), and the SCA $\times$ location interaction was significant for seeds per capsule and yield per plant (Table 2). These significant interactions suggested that the selection of different parental genotypes and specific hybrids was required for developing populations specific to each location.

\subsection{Genetic components for Seed yield per plant and its components across different environments}

Genetic components for seed yield and its components (capitula per plant, seeds per capitulum and 1000- seed mass) are presented in Table 3 . The higher proportion of $\delta_{\mathrm{D}}^{2}(1.66)$ to $\delta_{\mathrm{A}}^{2}(1.1)$ and dominance ratio (1.73) implied the predominance role of dominance gene action, rather than the additive one, for the genetic control of capitula per plant (Table 2). This finding was similar to those obtained in the previous reports (Shahbazi and Saeidi 2007; Golkar et al., 2012; Deedawat et al 2015). According to the obtained results, the large proportion of $\delta^{2}{ }_{\mathrm{A}}$ to $\delta^{2}{ }_{\mathrm{D}}$ and dominance ratio (less than unity) indicated the predominance role of additive gene effects, rather than the dominance ones, in the genetic control of seeds per capitulum and seed mass in safflower. Our findings were consistent with previous reports (Mandal and Banerjee 1997; Shahbazi and Saeidi 2007; Nakhaei et al 2014). The comparison of the magnitude of $\delta_{\mathrm{GCA}}^{2}(12.61)$ and $\delta_{\mathrm{SCA}}^{2}(0.0017)$ and dominance ratio (1.01) for seed yield per plant indicated the additive - dominance genetic control of this trait (Table 2). The previous studies observed the predominant role of dominance gene action for seed yield per plant (Singh et al 2008; Deedawat et al 2015) and additive gene action in salinity stress (Nakhaei et al 2014). So, this new type of genetic control for the seed yield of safflower per plant could be utilized by both breeding methods based on selection and hybridization. 
Table 2: Analysis of variance for combining ability for agronomic traits in safflower under different environment

\begin{tabular}{|c|c|c|c|c|c|}
\hline \multirow[b]{2}{*}{ Source of variation } & \multirow[b]{2}{*}{$\mathrm{df}$} & \multicolumn{4}{|c|}{ Mean squares of the studied traits } \\
\hline & & $\mathrm{CP}$ & $\mathrm{SC}$ & SW & YP \\
\hline Environment & 2 & $120.9^{* *}$ & $13515.1^{* * *}$ & $1017.4^{* * *}$ & $4213.7^{* *}$ \\
\hline Rep (Environment) & 6 & 12.99 & 39.55 & 55.9 & 65.9 \\
\hline Genotype & 35 & $27.84^{* *}$ & $227.28^{* *}$ & $137.54^{* *}$ & $365.1^{* *}$ \\
\hline GCA & 7 & $70.85^{* *}$ & $931.97^{* *}$ & $531.23^{* *}$ & $1282.7^{* *}$ \\
\hline SCA & 28 & $17.09^{* *}$ & 51.1 & $39.11^{* *}$ & $135.71^{* *}$ \\
\hline Gen $\times$ Environment & 70 & 2.88 & $68.44^{* *}$ & 16.48 & $21.9^{* *}$ \\
\hline GCA $\times$ Environment & 14 & $6.07^{*}$ & $234.50^{* *}$ & 29.72 & $31.5^{* *}$ \\
\hline $\mathrm{SCA} \times$ Environment & 56 & 2.08 & $26.93^{* *}$ & 13.18 & $19.5^{* * *}$ \\
\hline Error & 210 & 2.88 & 11.57 & 14.78 & 9.9 \\
\hline \multicolumn{6}{|l|}{ Genetic parameters } \\
\hline$\delta_{\mathrm{GCA}}^{2}$ & & 0.55 & 7.48 & 5.28 & 12.6 \\
\hline$\delta_{\mathrm{SCA}}^{2}$ & & 1.66 & 2.68 & 2.88 & 12.9 \\
\hline$\delta_{\mathrm{GCA}}^{2}: \delta_{\mathrm{SCA}}^{2}$ & & 0.33 & 2.79 & 1.83 & 0.97 \\
\hline$\delta_{\mathrm{A}}^{2}$ & & 1.1 & 14.96 & 10.56 & 25.2 \\
\hline$\delta_{D}^{2}$ & & 1.66 & 2.68 & 2.88 & 12.9 \\
\hline $\mathrm{h}_{\mathrm{b}}^{2}(\%)$ & & 0.87 & 0.70 & 0.86 & 0.93 \\
\hline $\mathrm{h}_{\mathrm{n}}^{2}(\%)$ & & 0.34 & 0.59 & 0.68 & 0.62 \\
\hline Dominance ratio & & 1.73 & 0.59 & 0.73 & 1.01 \\
\hline
\end{tabular}

CP: Capitula per plant, SC: seeds per capitulum, SW: 1000-seed weight, YP: yield per plant.

* and ** significant at $P<0.05$ and $P<0.01$, respectively

\subsection{Heritability of the traits}

The efficiency of selection largely depends on the extent of genetic variability present in the population and the heritability of the concerned character (Mohammadi and Pourdad, 2009; Acquaah, 2012). The broad- sense heritability ranged from $73(\%)$ in seeds per capitulum to $93(\%)$ in seed yield per plant (Table 2). High estimates of broad-sense heritability for seed yield and its components in this study denoted that dominance or epistatic effects as other types of genetic effects might be contributed in their variation. Although, the higher value of broad - sense heritability proposed that selection would be more effective and improvement could be expected for the traits in future breeding programs (Singh and Pawar, 2005; Mohammadi and Pourdad, 2009). The high broad- sense heritability for the number of seeds per capitulum (about $70 \%$ ) was similar to that in the previous reports (Mohammadi and Pourdad, 2009). A low value for the broad - sense heritability (about $60 \%$ ) of seed yield per plant was reported (Shahbazi and Saeidi, 2007; Mohammadi and Pourdad, 2009) that was different from that found in this study. Different methods for heritability estimation resulted in different values of heritability for the same trait (Acquaah, 2012). In $F_{2}$ generation, the narrow- sense heritability ranged from $34 \%$ for capitula per plant to $68 \%$ in seed mass (Table 2). The ranges of narrow-sense heritability in low and medium values $\left(13 \%<\boldsymbol{h}_{n}^{2}<68 \%\right)$ implied that a moderate progress would be achieved through selection for these traits.

\subsection{Parental GCA and SCA of the crosses}

Selecting parents based on their genetic merit is a vital component in the utilization of genetic resources. The estimates on $\mathrm{gca}$ effects and the mean performance of the parents would help the breeder to understand the genetic architecture and the potentiality of the selected parents in $\mathrm{F}_{2}$ and later generations (Suresh et al., 2013). The GCA effects for different traits across three environments are presented in Table 3. In the case of capitula per plant, $\mathrm{GE}_{62918}, \mathrm{~K}_{21}$ and Mex-22-191 possessed high positive GCA effects that were suitable for breeding programs aimed at increasing the number of capitula per plant in safflower (Table 3). The GCA effects for $\mathrm{CP}$ varied from $1.21\left(\mathrm{GE}_{62918}\right)$ to -1.03 $\left(\mathrm{ISF}_{14}\right)$ (Table 3). The mean of parental genotypes for $\mathrm{CP}$ varied from $26.20\left(\mathrm{GE}_{62918}\right)$ to $21.18\left(\mathrm{~A}_{2}\right)$ (Table 3). The seeds per capitula showed wide variation for GCA effects, from $-5.94\left(\mathrm{GE}_{62918}\right)$ to $3.07\left(\mathrm{C}_{4110}\right)$. The 
positive and significant GCA effects for $\mathrm{C}_{111}, \mathrm{C}_{4110}$, $\mathrm{ISF}_{14}$ and Mex.22-191 demonstrated the useful role of these genotypes in safflower breeding to improve the number of seeds per capitulum. The mean of seeds per capitulum for parental genotypes varied from 38.96
$\left(\mathrm{C}_{4110}\right)$ to $20.81\left(\mathrm{GE}_{62918}\right)$. The GCA effects for1000seed mass ranged from $-2.69\left(\mathrm{C}_{4110}\right)$ to 4.54 (IL.111). The highest mean for seed mass (41.09) was attributed to IL.111 (Table 3).

Table 3: General combining ability (GCA) effects and mean values for seed yield and different traits in safflower

\begin{tabular}{cccccccccccc}
\hline Trait & & $\mathrm{GE}_{62918}$ & $\mathrm{C}_{111}$ & $\mathrm{C}_{4110}$ & $\mathrm{ISF}_{14}$ & $\mathrm{~A}_{2}$ & $\mathrm{~K}_{21}$ & IL.111 & Mex.22-191 & $\left(\mathrm{g}_{\mathrm{i}}\right)$ & $\begin{array}{c}\text { LSD } \\
(\mathrm{mean})\end{array}$ \\
\cline { 3 - 11 } $\mathrm{CP}$ & $\mathrm{GCA}$ & 1.21 & -0.36 & -0.28 & -1.01 & -1.03 & 1.18 & -0.25 & 0.53 & 0.16 & \\
& Mean & 26.20 & 23.54 & 22.20 & 22.41 & 21.18 & 26.17 & 24.04 & 24.20 & & 1.57 \\
$\mathrm{SC}$ & GCA & -5.94 & 1.62 & 3.07 & 1.43 & -1.41 & 1.58 & -3.21 & 2.84 & 0.33 & \\
& Mean & 20.81 & 35.43 & 38.96 & 35.91 & 28.40 & 30.07 & 26.27 & 35.53 & & 3.16 \\
SW & GCA & 0.96 & -2 & -2.69 & -2.36 & 0.24 & -0.31 & 4.54 & 1.62 & 0.37 & \\
& Mean & 33.27 & 28.72 & 28.69 & 27.32 & 30.42 & 25.59 & 41.09 & 30.77 & & 3.57 \\
\hline
\end{tabular}

CP: capitula per plant, SC: seeds per capitulum (SC), SW: 1000-seed weight, YP: yield per plant.

\subsection{Specific combining ability of the crosses}

Estimates of SCA effects of the 28 crosses for CP, SC and $\mathrm{SW}$ across the combined data are given in Table 4.The scope exploitation of hybrids for further breeding cycles in any crop largely depends on 1) mean performance of the hybrids over a range of environments, and 2) the specific combining ability effects of the parents (Suresh et al., 2013). So, the hybrids identified based on SCA effects could be exploited in heterosis breeding (Zhang et al., 2015). The SCA for capitula per plant varied from 4.32( $\left.\mathrm{C}_{111} \times \mathrm{IL} .111\right)$ to $3.06\left(\mathrm{~A}_{2} \times \mathrm{IL} .111\right)$. However, the crosses of low $\times$ low GCA with the negative sign led to a superior hybrid with a positive sign indicating epistatic gene actions in controlling capitula per plant (Singh and Pawar, 2005). The specific combining ability for seeds per capitulum ranged from -5.09 $\left(\mathrm{ISF}_{14} \times \mathrm{GE}_{62918}\right)$ to $4.18\left(\mathrm{~A}_{2} \times \mathrm{GE}_{62918}\right)$ (Table 4). The specific combining ability effects for seed weight varied from $3.19\left(\mathrm{~A}_{2} \times \mathrm{ISF}_{14}\right)$ to $\mathrm{A}_{2} \times \mathrm{Mex} .22-191$ (3.94) (Table 4). According to the obtained results, the hybrid genotype compromising $\mathrm{A}_{2}$ with $\mathrm{GE}_{62918}$ and Mex.22191 could be used in breeding projects for the improvement of seeds per capitulum and seed weight in safflower, respectively. 
Pooran GOLKAR et al.

Table 4: Specific combining ability effects of different $\mathrm{F}_{2}$ generations for agronomic traits in safflower

\begin{tabular}{|c|c|c|c|}
\hline Crosses & $\mathrm{CP}$ & $\mathrm{SC}$ & SW \\
\hline $\mathrm{GE}_{62918} \times \mathrm{C}_{111}$ & 1.08 & -1.65 & -0.57 \\
\hline $\mathrm{GE}_{62918} \times \mathrm{C}_{4110}$ & -0.61 & 0.56 & 1.16 \\
\hline $\mathrm{GE}_{62918} \times \mathrm{ISF}_{14}$ & 1.25 & -5.09 & 1.43 \\
\hline $\mathrm{GE}_{62918} \times \mathrm{A}_{2}$ & -1.22 & 4.18 & 1.64 \\
\hline $\mathrm{GE}_{62918} \times \mathrm{K}_{21}$ & 0.09 & -0.69 & -1.78 \\
\hline $\mathrm{GE}_{62918} \times \mathrm{IL} 111$ & -0.24 & 0.57 & -1.70 \\
\hline $\mathrm{GE}_{62918} \times$ Mex.22-191 & -0.23 & 2.08 & 1.29 \\
\hline $\mathrm{C}_{111} \times \mathrm{C}_{4110}$ & 1.48 & 1.47 & -1.87 \\
\hline $\mathrm{C}_{111} \times \mathrm{ISF}_{14}$ & -0.46 & 0.82 & 1.60 \\
\hline $\mathrm{C}_{111} \times \mathrm{A}_{2}$ & -0.99 & -1.75 & 0.69 \\
\hline $\mathrm{C}_{111} \times \mathrm{K}_{21}$ & 1.32 & -1.98 & 2.46 \\
\hline $\mathrm{C}_{111} \times$ IL. 111 & -4.32 & 3.3 & -2.92 \\
\hline $\mathrm{C}_{111} \times$ Mex.22-191 & 1.00 & 0.76 & -0.67 \\
\hline $\mathrm{C}_{04110} \times \mathrm{ISF}_{14}$ & -1.18 & -1.35 & -1.33 \\
\hline $\mathrm{C}_{4110} \times \mathrm{A}_{2}$ & -0.18 & -4.77 & -2.15 \\
\hline $\mathrm{C}_{4110} \times \mathrm{K}_{21}$ & 0.57 & 0.38 & 0.26 \\
\hline $\mathrm{C}_{4110} \times \mathrm{IL} .111$ & 1.04 & -0.09 & 0.09 \\
\hline $\mathrm{C}_{4110} \times$ Mex.22-191 & 0.96 & 3.56 & -0.10 \\
\hline $\mathrm{ISF}_{14} \times \mathrm{A}_{2}$ & 1.39 & 3.92 & -3.19 \\
\hline $\mathrm{ISF}_{14} \times \mathrm{K}_{21}$ & -1.06 & 2.41 & -1.35 \\
\hline $\mathrm{ISF}_{14} \times \mathrm{IL} .111$ & -0.19 & -1.78 & 0.27 \\
\hline $\mathrm{ISF}_{14} \times$ Mex.22-191 & -0.92 & 0.37 & 2.63 \\
\hline $\mathrm{A}_{2} \times \mathrm{K}_{21}$ & -1.47 & 0.54 & 1.88 \\
\hline $\mathrm{A}_{2} \times \mathrm{IL} .111$ & 3.06 & 1.54 & 1.50 \\
\hline $\mathrm{A}_{2} \times$ Mex.22-191 & 0.58 & -0.75 & 3.94 \\
\hline $\mathrm{K}_{21} \times \mathrm{IL} .111$ & -0.12 & -2.25 & 1.58 \\
\hline $\mathrm{K}_{21} \times$ Mex.22-191 & 0.68 & 1.27 & 0.68 \\
\hline IL. $111 \times$ Mex.22-191 & -0.68 & -1.26 & 1.36 \\
\hline$\left(\mathrm{S}_{\mathrm{ij}}\right) \pm \mathrm{SE}$ & 0.44 & 0.89 & 1.01 \\
\hline$\left(\mathrm{S}_{\mathrm{ij}}-\mathrm{S}_{\mathrm{kl}}\right) \pm \mathrm{SE}$ & 0.71 & 1.43 & 1.62 \\
\hline$\left(\mathrm{S}_{\mathrm{ij}}-\mathrm{S}_{\mathrm{ik}}\right) \pm \mathrm{SE}$ & 0.76 & 1.52 & 1.71 \\
\hline
\end{tabular}

CP: capitula per plant, SC: seeds per capitulum, SM: 1000-seed weight.

\subsection{The Biplot graphs for seed yield per plant}

Existing new superior inbred lines with enhanced combining abilities is one of the goals of safflower breeding programs. Seed yield is a complicated multigenic trait that its yield depends on the great influence of environmental situations (Bočanski et al., 2011). In this study, the GGE biplot technique allowed the effective and rapid view of GCA and SCA effects of the parental genotypes, best lines and tester and their performance in different crosses in this study. Even though GGE biplot analysis of diallel data is widely used to determine combining ability and heterotic responses in many crops for yields, such as oil crops [rape seed (Sincik et al., 2011), cotton (Hamoud, 2014), maize (Bočanski et al., 2011; Badu-Apraku et al., 2013)] and forages such as alfalfa (Milić et al. 2011). This method has rarely been reported for diallel data analysis for safflower at multi location trials.
3.7.1 GCA and SCA of the parents for seed yield per plant

The GCA and SCA of parental genotypes are presented in Figure 1. Biplot accounted for $87.5 \%\left(\mathrm{PCA}_{1}=\right.$ $66.1 \% ; \mathrm{PCA}_{2}=23.3 \%$ ) of the total variance, which was partitioned, according to conventional analysis by Griffing, to GCA of parental genotypes and SCA of its crosses. General combining abilities of parents (entries) were increased in the direction of the arrow on ATC (Average Tester Coordinate) abscissa, ranking the genotypes by their GCA, as shown: $\mathrm{G}_{8}$ (Mex.22-191) > $\mathrm{G}_{6}\left(\mathrm{~K}_{21}\right)>\mathrm{G}_{3}\left(\mathrm{C}_{4110}\right)>\mathrm{G}_{2}\left(\mathrm{C}_{111}\right)>\mathrm{G}_{7}$ (IL.111) $>\mathrm{G}_{4}$ (Isf-14) $>\mathrm{G}_{5}\left(\mathrm{~A}_{2}\right)>\mathrm{G}_{1}\left(\mathrm{GE}_{62918)}\right.$ (Figure 1). The highest (40.37) and lowest (23.22) means for yield per plant were observed at $\mathrm{K}_{21}$ and $\mathrm{GE}_{62918}$, respectively. Therefore, it is necessary to select parents with high general GCA, so that it would benefit the offspring for seed yield and its components. 
The specific combining ability effects for seed yield per plant ranged from $-9.41\left(\mathrm{C}_{4110} \times \mathrm{ISF}_{14}\right)$ to $5.36\left(\mathrm{~K}_{21} \times\right.$ Mex.22-191) and $A_{2} \times$ Mex.22-191) (Figure 1). So, by considering the positive and significant GCA effects of parental genotypes of this cross, the $\mathrm{K}_{21} \times$ Mex.22-191 cross with the highest positive SCA for yields per plant could the best cross combination for developing high yielding hybrid safflower varieties.

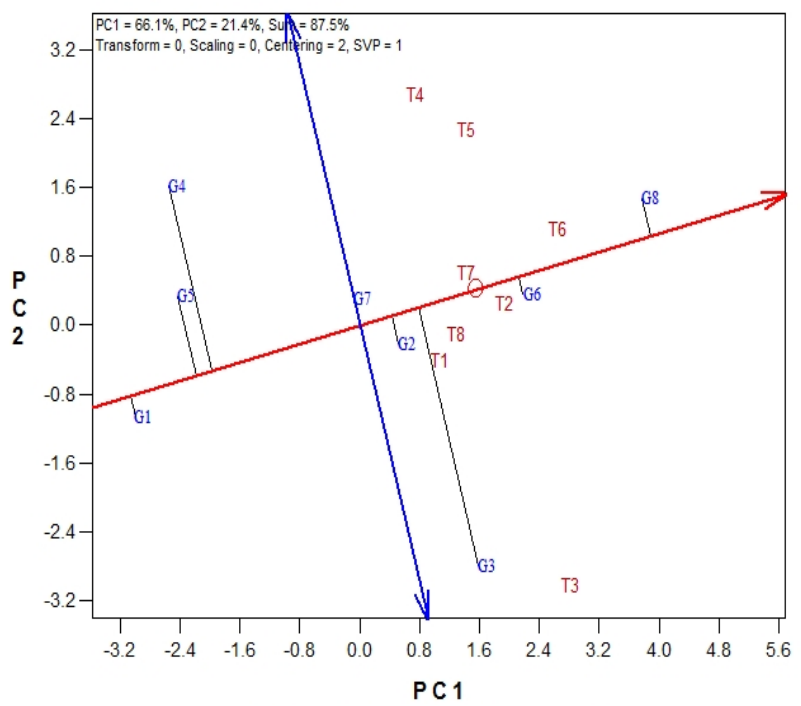

Figure 1: The biplot based on diallel data for seed yield per plant with the average tester ordination view, for representation of GCA and SCA of eight parental genotypes in safflower. Codes of the genotypes are: $\mathrm{G}_{1}=$ $\mathrm{GE}_{62918}, \mathrm{G}_{2}=\mathrm{C}_{111}, \mathrm{G}_{3}=\mathrm{C}_{4110}, \mathrm{G}_{4}=\mathrm{ISF}_{14}, \mathrm{G}_{5}=\mathrm{A}_{2}, \mathrm{G}_{6}=\mathrm{K}_{21}, \mathrm{G}_{7}=\mathrm{IL} .111$ and $\mathrm{G}_{8}=$ Mex.22.191; codes of the testers are: $\mathrm{T}_{1}=\mathrm{GE}_{62918}, \mathrm{~T}_{2}=\mathrm{C}_{111}, \mathrm{~T}_{3}=\mathrm{C}_{4110}, \mathrm{~T}_{4}=\mathrm{ISF}_{14}, \mathrm{~T}_{5}=\mathrm{A}_{2}, \mathrm{~T}_{6}=\mathrm{K}_{21}, \mathrm{~T}_{7}=\mathrm{IL} .111$ and $\mathrm{T}_{8}=$ Mex.22.191.

\subsubsection{Heterotic groups detection for seed yield per plant}

Identifying, developing and retaining broad-range of heterotic germplasms should be considered as an important aim in safflower breeding. It is not be expected that heterosis could be occurred in highly recombinant germplasm either, since crossing populations that are very distant results to a loss of advantageous epistatic effects (complementary gene interactions) that exist within parental populations (Sakiroglu and Brummer, 2007; Milić et al., 2011). GGE biplot could discriminate the heterotic groups in this study. According to tester vector, the $\mathrm{PCA}_{1}$ scores were positive for all testers. According to Figure 2, the genotypes of $4\left(\mathrm{ISF}_{14}\right), 5\left(\mathrm{~A}_{2}\right)$ and $6\left(\mathrm{~K}_{21}\right)$ were one group located above $\mathrm{PC}_{2}$ guideline, and the genotypes of $\mathrm{G}_{1}\left(\mathrm{GE}_{62918}, \mathrm{G}_{2}\left(\mathrm{C}_{111)}, \mathrm{G}_{3}\left(\mathrm{C}_{4110}\right)\right.\right.$ and $\mathrm{G}_{8}$ (Mex.22-191) were the other group located below the $\mathrm{PC}_{2}$ guideline. Moreover, testers of $T_{4}, T_{5}$ and $T_{6}$ interacted positively with genotypes $\mathrm{G}_{4}\left(\operatorname{Isf}_{14}\right), \mathrm{G}_{5}\left(\mathrm{~A}_{2}\right), \mathrm{G}_{6}\left(\mathrm{~K}_{21}\right), \mathrm{G}_{7}$ (IL.111) and $\mathrm{G}_{8}$ (Mex.22-191), but they interacted negatively with $\mathrm{G}_{1}\left(\mathrm{GE}_{62918}\right), \mathrm{G}_{2}\left(\mathrm{C}_{111}\right)$ and $\mathrm{G}_{3}\left(\mathrm{C}_{4110}\right)$. Similarly, testers $T_{1}, T_{2}, T_{3}$ and $T_{8}$ interacted positively with $G_{1}$ $\left(\mathrm{GE}_{62918}\right), \mathrm{G}_{2}\left(\mathrm{C}_{111}\right)$ and $\mathrm{G}_{3}\left(\mathrm{C}_{4110}\right)$. This interaction pattern clearly indicated heterosis in twelve crosses, which was $(4,5,6) \times(1,2,3,8)$ and defined as better than those in both parents. Heterosis could also occur between germplasms that are divergent and genetically distant, s something not necessarily dependent on geographic origin (Sakiroglu and Brummer 2007). Similar to this report, safflower genotypes with different geographical regions from Iran (Isfahan, Azarbayejan and Kordestan) and three genotypes with different country origins (Germany, Iran and Mexico) were grouped at the same heterotic groups. Tester 7 (IL.111), which was located near the ATC abscissa, did not seem to belong to any of the groups. An ideal tester should be discriminating of the entries and be highly representative of all testers (Yan \& Hunt, 2002). So, the T6 was the best tester in this data set. 


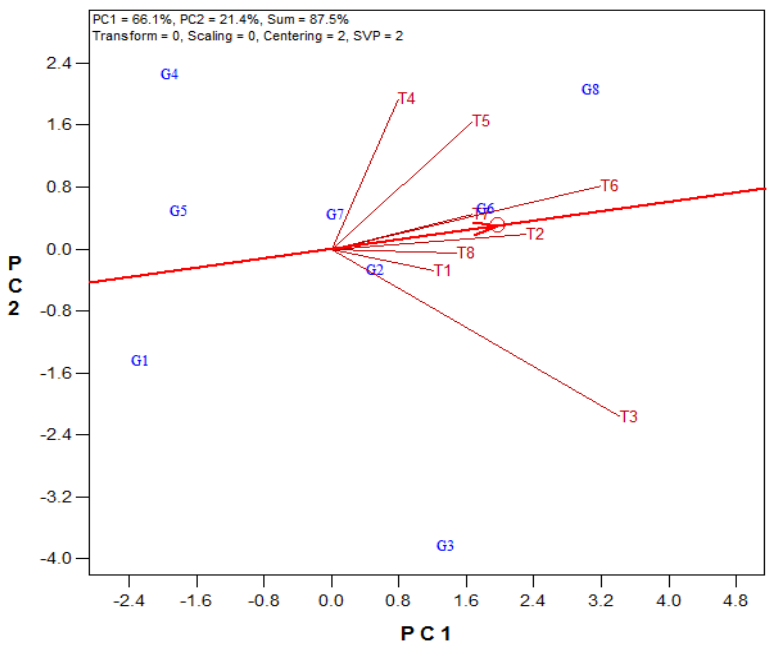

Figure 2: Determination of heterotic groupings by the average tester coordination for seed yield per plant in safflower. Codes of the genotypes are: $\mathrm{G}_{1}=\mathrm{GE}_{62918}, \mathrm{G}_{2}=\mathrm{C}_{111}, \mathrm{G}_{3}=\mathrm{C}_{4110}, \mathrm{G}_{4}=\mathrm{ISF}_{14}, \mathrm{G}_{5}=\mathrm{A}_{2}, \mathrm{G}_{6}=\mathrm{K}_{21}, \mathrm{G}_{7}=$ IL.111 and $\mathrm{G}_{8}=$ Mex.22.191; Codes of the testers are: $\mathrm{T}_{1}=\mathrm{GE}_{62918}, \mathrm{~T}_{2}=\mathrm{C}_{111}, \mathrm{~T}_{3}=\mathrm{C}_{4110}, \mathrm{~T}_{4}=\mathrm{ISF}_{14}, \mathrm{~T}_{5}=\mathrm{A}_{2}, \mathrm{~T}_{6}=$ $\mathrm{K}_{21}, \mathrm{~T}_{7}=\mathrm{IL} .111$ and $\mathrm{T}_{8}=$ Mex.22.191.

\subsubsection{Polygon view of the biplot for seed yield per plant}

According to Figure 3, the biplot was divided into four sectors, with genotypes $\mathrm{G}_{8}$ (Mex.22-191), $\mathrm{G}_{4}\left(\mathrm{Isf}_{14}\right), \mathrm{G}_{1}$ $\left(\mathrm{GE}_{62918}\right)$ and $\mathrm{G}_{3}\left(\mathrm{C}_{4110}\right)$ as the corner genotypes. No testers fell in the $\mathrm{G}_{1}\left(\mathrm{GE}_{62918}\right)$ and $\mathrm{G}_{4}\left(\mathrm{Isf}_{14}\right)$ sectors, suggesting that genotypes of 1 and 4 were not the best mating parents with any of the genotypes. Moreover, this showed that these genotypes produced the poorest hybrids with some or all of the testers. As the single tester $\left(T_{3}\right)$ fell in the $\mathrm{G}_{3}\left(\mathrm{C}_{4110}\right)$ sector, $\mathrm{G}_{3}\left(\mathrm{C}_{4110}\right)$ was the best mating partner with $\mathrm{T}_{3}$. All of the testers, except $\mathrm{T}_{3}$, fell in the $\mathrm{G}_{8}$ (Mex.22-191)sector, indicating that the genotype 8 (Mex.22-191) was the best mating parent with the mentioned testers, but the crosses of G8 (Mex.22-191) by testers of 6 and 5 were better to some extent. According to the polygon view at Fig 3, the best crosses for seed yield were represented by G8 (Mex.22$191) \times \mathrm{G} 5\left(\mathrm{~A}_{2}\right)$ and G8 (Mex.22-191) $\times \mathrm{G} 6\left(\mathrm{~K}_{21}\right)$.

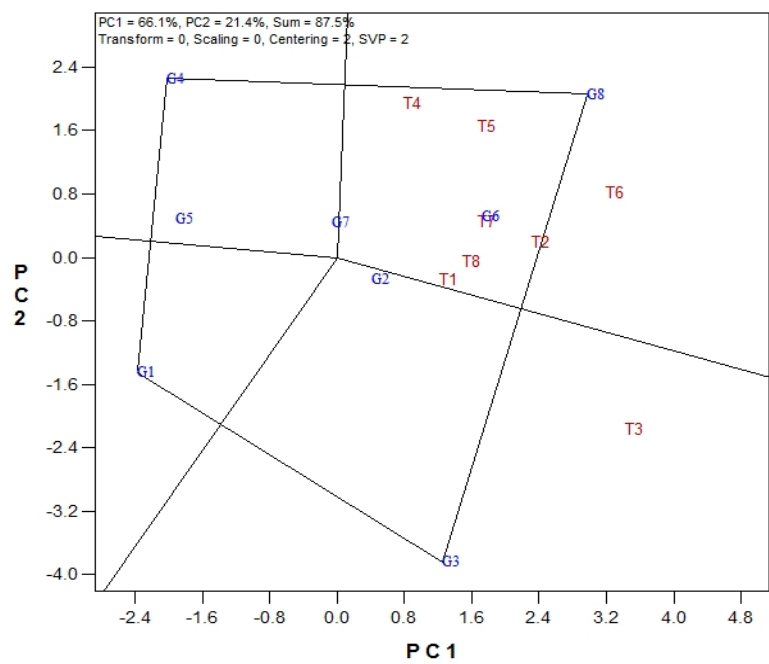

Figure 3: Polygon view of the biplot, showing the best crosses among all possible combinations for seed yield per plant in safflower. Codes of the genotypes are: $\mathrm{G}_{1}=\mathrm{GE}_{62918}, \mathrm{G}_{2}=\mathrm{C}_{111}, \mathrm{G}_{3}=\mathrm{C}_{4110}, \mathrm{G}_{4}=\mathrm{ISF}_{14}, \mathrm{G}_{5}=\mathrm{A}_{2}, \mathrm{G}_{6}=\mathrm{K}_{21}$, $\mathrm{G}_{7}=\mathrm{IL} .111$ and $\mathrm{G}_{8}=$ Mex.22.191; codes of the testers are: $\mathrm{T}_{1}=\mathrm{GE}_{62918}, \mathrm{~T}_{2}=\mathrm{C}_{111}, \mathrm{~T}_{3}=\mathrm{C}_{4110}, \mathrm{~T}_{4}=\mathrm{ISF}_{14}, \mathrm{~T}_{5}=\mathrm{A}_{2}$, $\mathrm{T}_{6}=\mathrm{K}_{21}, \mathrm{~T}_{7}=\mathrm{IL} .111$ and $\mathrm{T}_{8}=$ Mex.22.191. 


\section{CONCLUSION}

This study was undertaken to study combining ability $x$ environment interaction in safflower by diallel design. Combining ability $\times$ environment interaction was carried out to regulate testing over more than one environment for population improvement purposes and the early testing of superior safflower new hybrids. High-yielding cultivars could be especially necessary to ensure success for safflower cultivation in arid and semi arid regions of Iran. So, this study revealed the importance of gaining knowledge about combining ability and the identification of superior genotypes across different environments. Considering the contribution of different genetic components in genetic control of a trait showed that an appropriate strategy for improvement of each desirable trait could be achieved. It may also be worthwhile to attempt bi-parental mating in the segregating generation among some selected crosses such as $A_{2} \times$ Mex.22-191 and $K_{21} \times$ IL.111 and $\mathrm{A}_{2} \times$ IL.111 to permit superior recombination. The greater negative GCA values of IL.111 for seed mass, $\mathrm{K}_{21}$ for capitula per plant and yield per plant, and $\mathrm{C}_{4110}$ for seeds per capitulum imply the capacity of these parents in producing superior progenies when combined with another parent for improving the noted traits, respectively. In this study, the superior genotypes across three environments could be used in recombination breeding programs to accumulate suitable genes responsible for improving seed yield in safflower.

\section{REFERENCES}

Acquaah, G. (2012). Principles of plant genetics and breeding. $2^{\text {nd }}$ Edition. Wiley-Blackwell, Oxford. doi:10.1002/9781118313718

Barten, J.H., Elkind, Y., Scott, J.W., Vidavski, S. \& Kedar, N. (1993). Diallel analysis over two environments for blossom-end scar size in tomato. Euphytica, 65, 229-237. doi:10.1007/BF00023087

Bočanski, J., Nastasić, A., Stanisavljević, D., Srečkov, Z., Mitrović,B., Treskić , S., \& Vukosaljev, M. (2011). Biplot analysis of diallel crosses of NS maize inbred lines. Genetica, 43(2), 277-284. doi:10.2298/gensr1102277b

Badu-Apraku, B., Oyekunle, M., Fakorede, M.A. B., Vroh,I., Akinwale, R.O., \& Aderounmu, M. (2013). Combining ability, heterotic patterns and genetic diversity of extra-early yellow inbreds under contrasting environments. Euphytica, 192, 413-433. doi.:10.1007/s10681-013-0876-4

Dajue, L. \& Mundel, H.H. (1996). Safflower (Carthamus tinctorius L.). IPGRI, Italy.

Deedawat, S.K., Patel, S.R., Patil, S.S., \& Patel, N.N. (2015). Combining ability studies on yield, oil content and other traits in safflower (Carthamus tinctorious L.). Green Farming International Journal, 6(5), 991-993.

Golkar, P., Arzani, A. \& Rezai, A.M.. 2012. Genetic Analysis of Agronomic Traits in Safflower (Carthamus tinctorious L.). Notulae Botanicae Horti Agrobotanici Cluj-Napoca, 40(1):276-281.

Golkar, P. (2014). Breeding improvements in safflower (Carthamus tinctorius L.): A review. Australian Journal of Crop Science, 8(7),1079-1085.
Gouda, R.K., Kage, U., Lohithaswa, H.C., Shekara, B.G., \& Shobha, D. (2013). Combining ability studies in maize (Zea Mays L.). Molecular Plant Breeding, 3(14), 116-127. doi:10.5376/mpb.2013.04.0014

Griffing, B. (1956). Concept of general and specific combining ability in relation to diallel crossing systems. Australian Journal of Crop Science , 9, 463-493. doi:10.1071/bi9560463

Gupta, R.K. \& Singh, S.B. (1988). Diallel analysis for seed yield, oil content and other economic traits in safflower (Carthamus tinctorius L.). GenetikaYugoslavia, 20,161-173.

Hamoud, H.M.E. (2014). Use of biplot approach for genetic analysis of yield and related traits in cotton (Gossypium barbadense). Journal of Plant Breeding and Crop Science, 6, 41-47. doi:10.5897/JPBCS2013.0432

Kizil, S., Çakmak, O., Kirici, S., \& Inan, M. (2008). A comprehensive study on safflower (Carthamus tinctorius L.) in semi-arid conditions. Biotechnology and Biotechnology Equipment, 22(4), 947-953. doi:10.1080/13102818.2008.10817585

Knowles, P.F. (1969). Centers of plant diversity and conservation of crop germplasm Safflower. Economic Botany, 23, 324-329. doi:10.1007/BF02860678

Mandal, A.B. \& Banerjee, S.P. (1997). Diallel analysis of yield and yield components in safflower (Carthamus tinctorius L.). Genetics and Breeding, 51, 211-215. 
Milić, D., Katić,S., Karagić, D., Gvozdanović-Varga, J., Petrović and, S. \& Bočanski, J. (2011). Genetic control of agronomic traits in alfalfa (M. sativa ssp.sativa L.). Euphytica, 182, 25-33. doi:10.1007/s10681-011-0434-X

Mohammadi, R. \& Pourdad, S.S. ( 2009). Estimation, interrelationships and repeatability of genetic variability parameters in spring safflower using multi-environment trial data. Euphytica, 165:313324. doi:10.1007/s10681-008-9789-z

Nakhaei, M., Baghizadeh,A., Mohammadi-Nejad, G., \& Golkar, P. (2014). Genetic analysis of salt tolerance in safflower (Carthamus tinctorius L.). Annual Research and Review in Biology, 4(1), 337-346. doi:10.9734/ARRB/2014/5909

Nassimi, A.W., Raziuddin, R., Ali, S., Hassan, G., \& Ali, N. (2006). Combining analysis for maturity and other traits in rapeseed (Brassica napus L.). Journal of Agronomy, 5(3), 523-526. doi:10.3923/ja.2006.523.526

Perkins, J.M. (1970). Environmental and genotypeenvironmental components of variability. VI. Diallel sets of crosses. Heredity, 25, 29-40. doi:10.1038/hdy.1970.4

Sakiroglu, M. \& Brummer, E.C. (2007). Little heterosis between alfalfa populations derived from the midwestern and southwestern United States. Crop Science, $\quad 47, \quad 2364-2371$. doi:10.2135/cropsci2006.12.0803

SAS Institute. (2011). Base SAS 9.3 Procedures guide. SAS Inst., Cary, NC.

Shahbazi, E. \& Saeidi, Gh. 2007. Genetic analysis for yield components and other agronomic characters in safflower (Carthamus tinctorius L.). Genetics and Breeding, 36, 11-20.
Sincik, M., Goksoy, A.T., Turan, Z.M. (2011). The heterosis and combining ability of diallel crosses of rapeseed inbred lines. Notulae Botanicae Horti Agrobotanici Cluj-Napoca, 39(2), 242-248.

Singh, S. \& Pawar, I.S. (2005). Theory and Application of Biometrical Genetics. CBS Press.

Singh, V., Kolekar , N.M., \& Nimbkar, N. 2005. Breeding strategy for improvement of flower and seed yield in safflower. The $7^{\text {th }}$ International Safflower Conference. Wagga Wagga, Australia.

Suresh, R., Chandra Babu R., S. Michael Gomez \& Shanmugasundaram, P. (2013). Genetic analysis of yield traits in rice under irrigated and water stress environments. Indian Journal of Genetics, 73 (2), 162-168. doi:10.5958/j.0975-6906.73.2.023

Weiss, E.A. (2000). Oil seed Crops. $2^{\text {nd }}$ ed. Blackwell, London.

Yan, W. \& Hunt, L.A. (2002). Biplot analysis of diallel data. Crop Science, 42, 21-30. doi:10.2135/cropsci2002.0021

Yan, W. (2001). GGE biplot- A Windows application for graphical analysis of multi- environment trial data and other types of two-way- data. Agronomy Journal, 93, 1111-1118. doi:10.2134/agronj2001.9351111x

Zhang, Y., Kang, M.S., \& Lamkey, K.R. (2005). Diallel-SAS 05: A comprehensive program for Griffing's and Gardner-Eberhart analysis. Agronomy Journal, 97, 1097-1106. doi:10.2134/agronj2004.0260

Zhang, X., Lv, CH., Guo, B., \& Rugen, Xu. (2015). Combining ability of different agronomic traits and yield Components in hybrid barley. PLoS One, 10(6), $\mathrm{e} 0126828$. 